\title{
SOME PARAMETERS AFFECTING ON BALER PERFORMANCE
}

\author{
M. A. A., Mady
}

\begin{abstract}
Baling is essentially packaging performed to facilitate handling, transport, and storing using the baling machines. The present study was conducted to investigate some operating parameters which affecting on the performance of baler such as forward speed; material moisture content and baler feed rate on the baler performance. The field experiments were carried out at Libya on four baler forward speeds (1.5, $3.0,4.5$, and $6.0 \mathrm{~km} / \mathrm{h})$; four levels of moisture content $(8-10,11-13,14$ 16, 17-19\%) and various baler feed rates of (1.3, 2.5, 3.9 and 5,2 ton / h). The study indicated that, increasing baler forward speeds from 1.5 to $6.0 \mathrm{~km} / \mathrm{h}$ increased field capacity by $51 \%$, bale productivity by $47 \%$ and fuel consumption rate by 53\%. On the other hand, increasing baler forward speed tends to decrease field efficiency by 35\%, bale density by $33 \%$, and energy requirements by $41 \%$. Increasing material moisture content from 8-10 to $17-19 \%$ and baler feed rates from 1.3 to 5.2 ton/h Increased the bale density by 15 to 20\%; 8 to 13\% respectively; and decreased the size required for storing bales by $20 \%$., increasing material moisture content of bale straw from 11 to $13 \%$ decreased the fuel consumption and energy requirements by $15 \%$.
\end{abstract}

\section{INTRODUCTION}

The continuous increase in cost of removing field residues is
considered from the policy of agriculture intensification so, care
had to be taken to remove field residues to void severe dangerous such as losses, pollution of environment, public health hazard, and possibility of fire eruption. In general, straw, hay, and crop residues as field raw material are used in animal nutrition. These materials are

\section{Engineering Department, Faculty of Agriculture, Suez Canal University, 41522, Ismailia, Egypt}


introduced to animals either after being chopped or baled. In another saying, there are great efforts towards recycling rice straw to reduce the environmental pollution during rice threshing season and rapidly clear the fields from straw for useful applications as animal feeds and paper and wood industry. Other utilization techniques may be represented in composting to produce organic fertilizers (Saher, 2008). Agricultural Magazine, (1999) discussed the environmental hazard caused by farmers who are usually burn straw yield at the end of the rice harvesting season. Burning rice straw may increase the temperature of the soil surface layer, causing pests killing. The frequent straw burning may cause subsoil hard pan, which makes the drainage difficult, restricts seeding emergence. Srivastava et al. (1993) mentioned that the two types of balers in popular use for baling straw and other fibrous materials are rectangular and round baler. They added that the bale density of the straw is affected by the type of material being baled, its moisture content at time of baling, and resistance provided by convergence of the bale chamber. In this respect Morad, (1996) found that, bale density increased by increasing the feeding rate and the moisture content of the material being baled. The optimum bale density was obtained by using the plunger-type field baler(36x $46 \mathrm{~cm}$ bale chamber) at feeding rates ranged from 4.2to6.0 ton / $\mathrm{h}$, and the moisture content of rice straw bales ranged from 15 to $20 \%$. He also found that; baling power increased (by 21\%) by increasing baler feed rate (from 1.4 to 4.4 ton /fed.). Meanwhile, the material moisture content was found in the opposite of that sequence. It decreased (16\%) by increasing moisture content (from 8 to 20\%) during baling wheat straw. This also is agrees with El-danasory and Imbabi, (1998) who indicated that, the baler capacity was affected by weight of straw yield and forward speed. Baler losses decreased by increasing the forward speed while it is reduced by reducing the period after harvesting. They also found that the energy requirement increased with an increase of both the baler feeding rate and the forward speed of baler along windrow. The cost of using baler to pick up baling straw was half of cost compared to the manual method. 
Abd El-Mottaleb, (2002) found that the pick up baler requires minimum values of fuel, power and energy $7.5 \mathrm{lit} / \mathrm{fed} ., 13.8 \mathrm{~kW}$ and $20.3 \mathrm{kWh} / \mathrm{fed}$ respectively of rice straw, while maximum values were noticed with the use of both round baler 14 lit/fed. $27 \mathrm{kWand} 38 \mathrm{~kW} . \mathrm{h} / \mathrm{fed}$ of rice straw and stationary baler $28 \mathrm{lit} / \mathrm{fed} .19 \mathrm{~kW}$ and $76 \mathrm{~kW}$. h /fed respectively of rice straw. Afify et al. (2002) stated that the baler productivity and the bale density increased by about $25 \%$ and $30 \%$ as the baler feeding rates increased from 1.8 to 2.2 ton/fed, respectively. The total cost of baling decreased with an increase of baler feeding rates. The highest value of total cost of baling 682.5 L.E./h was obtained at the lowest of the baler feeding rate 1.5 ton/fed. The total cost of the baling decreased by about $30 \%$ when the baler feeding rate increased from 1.8 to 2.2 ton/ h.The average value of the total cost of baling using manual picking up increased by about $40 \%$ compared with that at the mechanical picking up. These may be due to the increase in the total workers required for collecting the straw and feeding the baler with manually. The results obtained by Morad et al. (2002) revealed that bale density, baling power, size for storing bales and criterion cost were in the optimum region under the following condition: (1) Pickup baler forward speed of between 2-3 km $/ \mathrm{h}$, ( 2)Baler feed rates of between 2.1to3.0ton $/ \mathrm{h}, 1.7$ to 2.5 ton $/ \mathrm{h}$, and 4.1 to 5.7 ton $/ \mathrm{h}$ during baling rice straw, wheat straw and berseem respectively, (3) material moisture content of between 12 to $15 \%, 9$ to $12 \%$, and 20 to $25 \%$ for baling rice straw, wheat straw, and berseem respectively. Statistical analysis for the two methods of feeding that the $4 \mathrm{~km} / \mathrm{h}$ baler forward speed is the best could be recommended with the mechanical feeding by Afify et al. (2005) the baler productivity with the mechanical feeding was decreased by $47 \%$. There was no appreciable change in the baler density between the two methods of feeding. On the other hand, feeding rate of 2.2 ton $/ \mathrm{h}$ may be considered as the better feeding rate with manual feeding under study. El-Gindy, et al. (2009) recommended that, the best span between thresher and belt conveyer was $2.0 \mathrm{~m}$ with conveyer speed of $1.47 \mathrm{~m} / \mathrm{s}$ for horizontal belt. These condition will reduced the pollution to $80 \%$ and reduce the baling cost. 
The present study was conducted to investigate some operating parameters such as forward speed, moisture content and baler feed rate on the baler performance.

\section{MATERIALS AND METHODS}

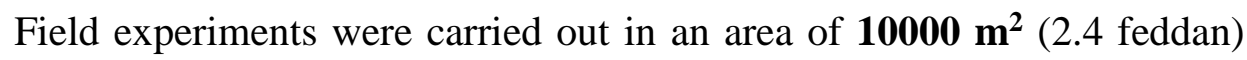
with dimensions of $125 \times 80 \mathrm{~m}$ during the Agricultural season of 2008 at the special farm in Sebha Governorate -Lybia, to study the performance of the pickup baler during baling barley straw. A pick up baler (Jone Deer; shown in Fig 1 and 2) with $1.6 \mathrm{~m}$ wide; pick up device having bale chamber of $36 \times 46 \mathrm{~cm}$ cross sectional area. It produces bale of $100 \mathrm{~cm}$ length with 2 wires per bale. The used baler was powered by tractor of 65 $\mathrm{hp}$; the baler includes the following functional components. A unit to pick up straw and elevate it to a conveyor to be moved to the balechamber entry, packers to place the straw in the chamber while the plunger is on its retracted stroke, a reciprocating plunger to compress the straw and move it through the bale chamber, means for applying forces to resist the movement of straw through the bale chamber and thus to control the degree of straw compression and the resultant bale density, an automatic device for controlling bale length, means of separating consecutive bales, binding the wires around each bale, and automatic typing when the bale reach the preselected length. The field experiments were conducted at four baler forward speeds $(1.5,3.0,4.5$, and $6.0 \mathrm{~km}$ $/ \mathrm{h}$ ); four levels of moisture content $(8-10,11-13,14-16,17-19 \%)$ and various baler feed rates of $(1.3,2.5,3.9$ and 5,2 ton/h). The baler performance was studied and the following points were taken in the consideration:-

* Actual field capacity, fed $/ \mathrm{h} . \quad *$ Fuel consumption rate, $1 / \mathrm{h}$.

* Field efficiency, $\% . \quad *$ Power requirements, $\mathrm{kW}$.

* Bale density, $\mathrm{kg} / \mathrm{m}^{3} \quad$ *Energy requirements, $\mathrm{kW} \mathrm{h} /$ ton.

* Size requirements for storing bales, $\mathrm{m}^{3} / \mathrm{fed}$ 


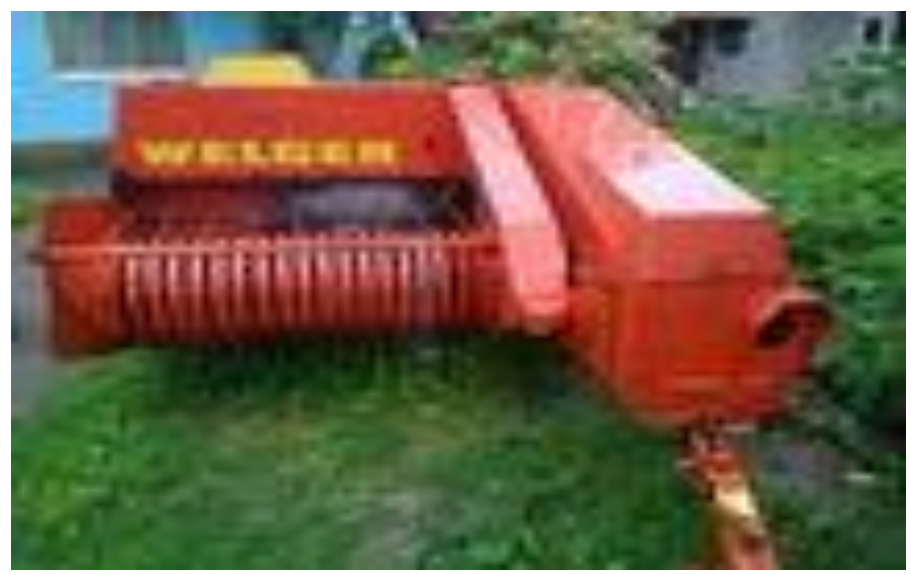

Figure (1). The baling machine

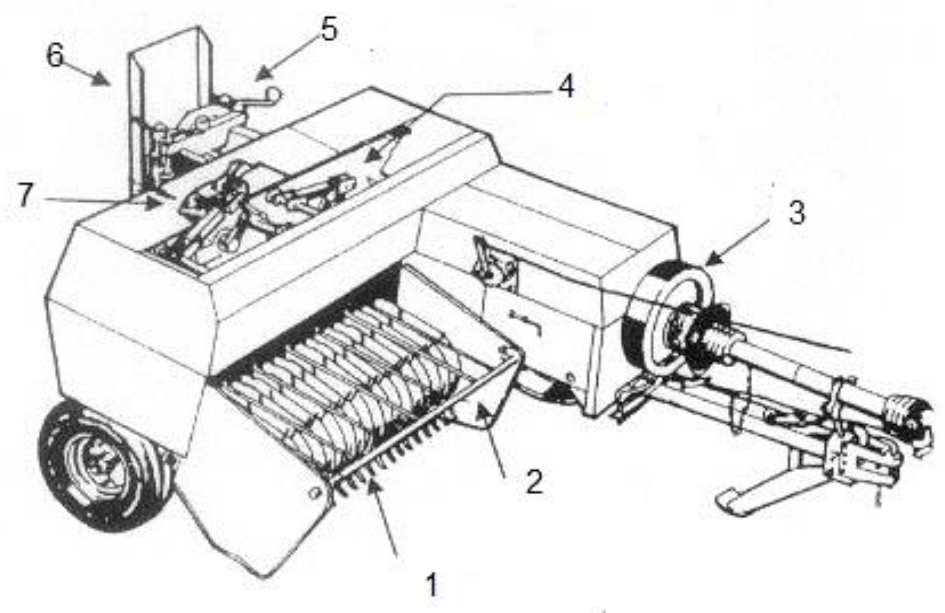

1- Pick up unite

4- Feeder yield to compressing chamber

7- Baling wire box

Figure (2). Schematic diagram illustrating the baler components

- The barley straw were harvested automatically by the reciprocating mower at cutting height $5 \mathrm{~cm}$. The area of experiment was about 4 feddans, this area was divided into two equal plots to study the effect of baler forward speeds and straw moisture content. The change in moisture 
content occurred as a result of an increase or decrease the amount of water added using a set of sprinklers along the line. The straw moisture content was determined before baler operating according to the standard methodology (ASTM, 1991).

-The actual field capacity $(\mathbf{F C} \mathbf{a c} ; \mathbf{f e d} / \mathbf{h})$ was calculated using the following equation:

$$
\mathrm{FC}_{\mathbf{a c}}=1 / \mathrm{Ta}
$$

Where,

Ta $=$ the actual time consumed for baling per feddan in $\mathrm{h} / \mathrm{fed}$

-The field efficiency $(\boldsymbol{E})$ in percent was calculated using the following equation:

$$
E=\mathbf{F C}_{\text {ac }} / \mathbf{F C}_{\text {th }}
$$

Where:

$\mathbf{F C}_{\mathbf{t h}}=$ the theoretical field capacity

-The bale density $\left(\mathbf{B d} ; \mathbf{k g} / \mathbf{m}^{\mathbf{3}}\right.$ ) was calculated using the following equation:

$$
\mathbf{B} \mathbf{d}=\mathbf{B} \mathbf{m} / \mathbf{B} \mathbf{v}
$$

Where:

$$
\begin{aligned}
& \mathbf{B m}=\text { Bale mass in } \mathbf{k g} . ; \\
& \mathbf{B} \mathbf{v}=\text { Bale volume in } \mathbf{m}^{\mathbf{3}} .
\end{aligned}
$$

-Size requirements for storing bales $\left(\mathbf{S} s \mathbf{b} ; \mathbf{m}^{\mathbf{3}} / \mathbf{f e d}\right)$ was calculated using the following equation:

$$
\mathbf{S s b}=\mathbf{S y}_{\mathbf{y}} / \mathbf{B d}_{\mathbf{d}}
$$

Where:

$$
\begin{aligned}
& \mathbf{S} \mathbf{s b}=\text { Size requirements for storing bales; } \mathbf{~ m}^{\mathbf{3}} / \mathbf{f e d} \text {. } \\
& \mathbf{S y}=\text { straw yield per feddan, } \mathbf{k g} / \mathbf{f e d} \text {. }
\end{aligned}
$$

-The power requirements $(\mathbf{P} ; \mathbf{k W})$ was calculated using the following formula:

$$
P=F c \times C V . \times \xi_{\text {th }} \times 427 \times(1 / 75)(1 / 1.36)
$$

Where:

$$
\begin{aligned}
& \mathbf{P}=\text { The power requirements, } \mathbf{k W} \text {; } \\
& \mathbf{F c}=\text { Fuel consumption rate, } \mathbf{k g} / \mathbf{s e c} \text {; } \\
& \mathbf{C . V}=\text { Calorific value of fuel, }(\mathbf{c . v} .=\mathbf{1 0 0 0 0} \mathbf{k . c a l} . / \mathbf{~ k g}) \text {; }
\end{aligned}
$$


$\xi_{\text {th }}=$ Thermal efficiency of the engine, (is considered to be $\mathbf{3 0 \%}$ for diesel engine).;

427 = Thermo- mechanical equivalent, kg. m./ k.cal.;

The actual time consumed for baling per each ton was determined ( $\mathbf{T} \mathbf{c}$ ) and Energy requirements for baling ( $\mathbf{E}_{\mathbf{n}} ; \mathrm{kW} \mathrm{h} \mathrm{/} \mathrm{ton} \mathrm{)} \mathrm{was} \mathrm{calculated}$ using the following formula:

$$
\mathbf{E}_{\mathbf{n}}=\mathbf{P} / \mathbf{B p}
$$

Where:

$\mathbf{E}_{\mathbf{n}}=$ Energy requirements for baling; $\mathrm{kW} \mathrm{h} /$ ton

$\mathbf{B p}=$ Baler productivity, ton $/ \mathrm{h}$.

\section{RESULTS AND DISCUSSION}

\section{Effect of baler forward speed on the baler performance}

The results in Fig. 3 showed that, there is a positive relationship between the baler forward speed and field capacity. On the other side, there is an inverse relationship between the baler forward speed and field efficiency. the field capacity increased and field efficiency decreased with an increase of baler forward speed. The field capacity increased by $51 \%$ and field efficiency decreased by $35 \%$ when the baler forward speed increased from 1.5 to $6.0 \mathrm{~km} / \mathrm{h}$ decreasing field efficiency with an increase of baler forward speed may be due to the less theoretical time consumed in comparison with the other items of time losses.

The results in Fig. 4 indicated that, there is a positive relationship between the baler forward speed and bale productivity. While there is an inverse relationship between the baler forward speed and bale density. Increasing baler forward speed lead to increase bale productivity and decrease the bale density. The bale productivity increased by $47 \%$ and bale density decreased by $33 \%$ when the baler forward speed increased from 1.5 to $6.0 \mathrm{~km} / \mathrm{h}$. Decreasing bale density with an increase of baler forward speed may have been attributed to the decrease in the amount of material being pressed in the bale chamber as the speed of operation increased.

The results in Fig. 5 revealed that there is a positive relationship between the baler forward speed and fuel consumption rate. On the other side, there is an inverse relationship between the baler forward speed and 
energy requirements. Any increase in baler forward speed followed with an increase in fuel consumption rate $(\mathrm{L} / \mathrm{h})$ and decrease in the energy requirements $(\mathrm{kW} . \mathrm{h} / \mathrm{ton})$. Increasing baler forward speed from 1.5 to 6.0 $\mathrm{km} / \mathrm{h}$ lead to increase fuel consumption rate by $53 \%$ and decrease the energy requirements by $41 \%$. This result may be attributed to the energy used in driving the plunger and the energy required for overcome the rolling resistance decrease with an increase in the baler forward speed (Freeland et. al. 1988).

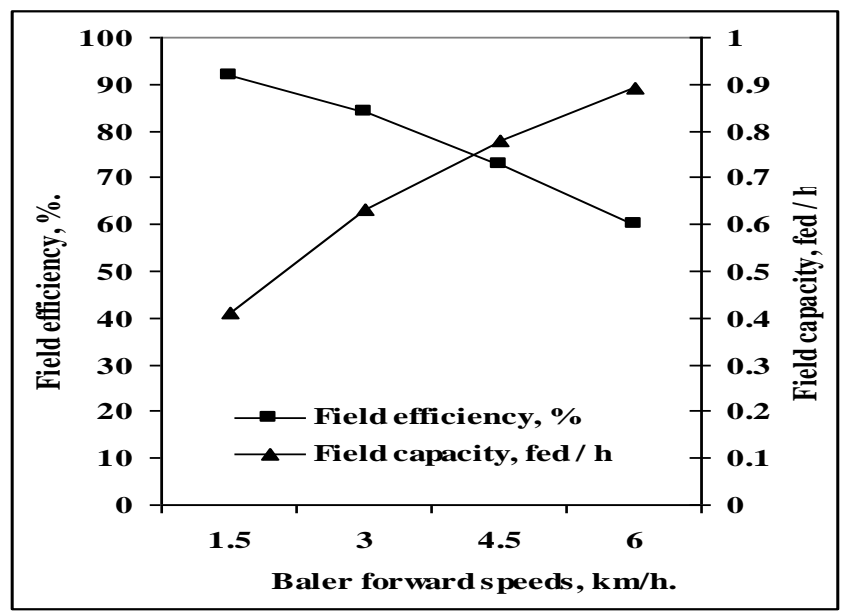

Figure (3). The average values of the field capacity (fed /h) and field efficiency at different baler forward speeds.

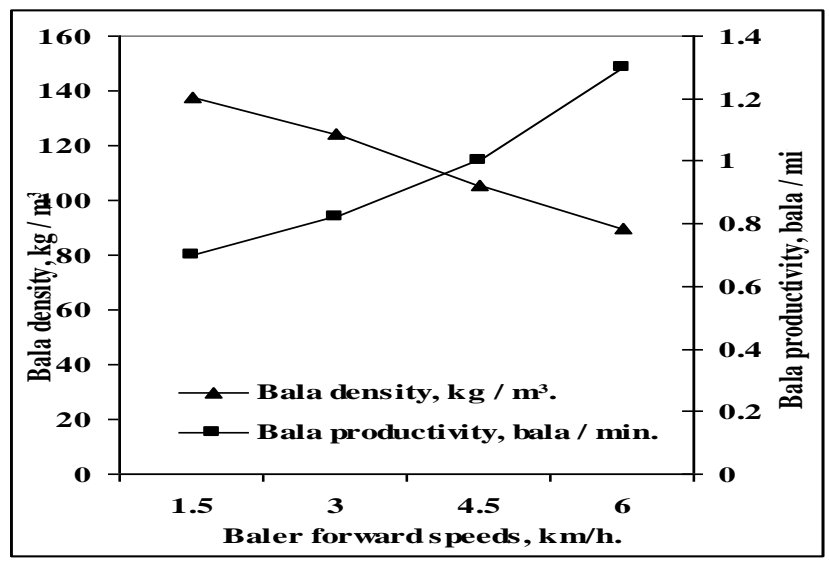

Figure (4). Indicate the effect of baler forward speed on the bale density and bale productivity. 


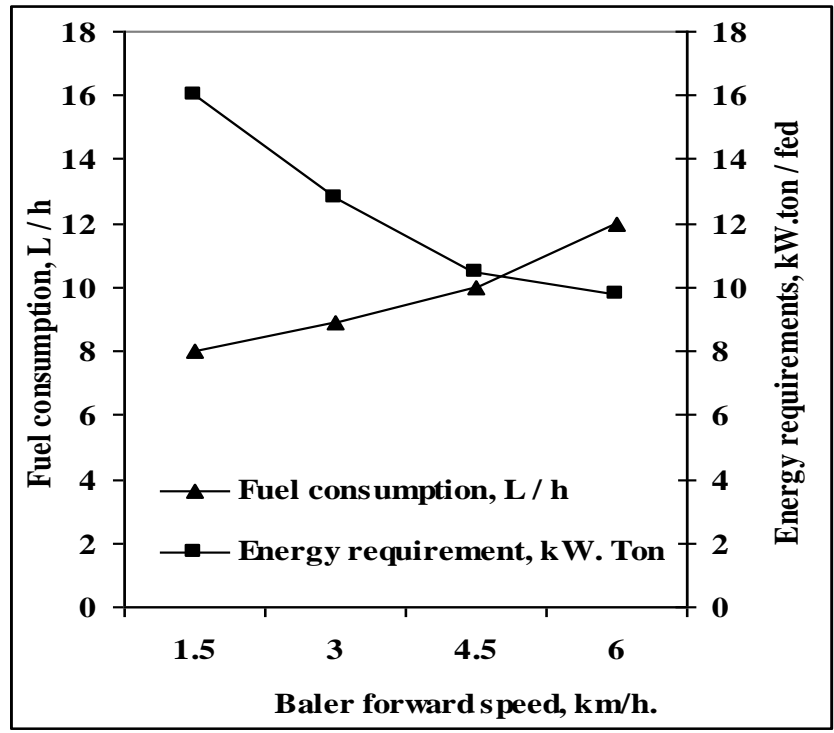

Figure (5). Effect of forward speed on the fuel consumption and energy requirements.

\section{Effect of material moisture content and baler feed rates on the baler} performance.

The results in Fig. 6 revealed that there is a positive relationship between the material moisture content and bale density. On the other side, there is an inverse relationship between the material moisture content and size required for storing bales. Increasing material moisture content from 10 to $19 \%$ for barley straw increased bale density by $20 \%$ and decreased the size required for storing bales by $20 \%$. The increasing in bale density by increasing material moisture content at a given adjustment may be due to the additional water, that tends to increase bale weight and consequently density.

The results in Fig. 7 indicated that, there is a positive relationship between the material moisture content and each of fuel consumption and energy requirements. Increasing material moisture content of barley straw from 11 to $13 \%$ decreased the fuel consumption and energy requirements by $15 \%$. Any further moisture content increase up to19\% fuel consumption rate and energy requirements will increase. 
The results in Fig. 8 indicated that increasing moisture content from 8 $10 ; 11-13 ; 14-16$ and $17-19 \%$ at feed rates of $1.3 ; 2.5 ; 3.9 ; 5.2 \mathrm{ton} / \mathrm{h}$ increased the bale density by $15.2 ; 17.3 ; 18.6 \%$ respectively. The increase in bale density by increasing moisture content at a given adjustment is attributed to the additional water, that tends to increase bale weight and consequently bale density. At the same time increasing baler feed rates from $1.3 ; 2.5 ; 3.9$ and 5.2 ton/h at moisture content from $8-10 ; 11-13 ; 14-16$ and $17-19 \%$ led to increase the bale density by 11 ; $12.6 ; 14.5 \%$ respectively. The increase in bale density by increasing baler feed rate may be attributed to the excessive weight of materials in the bale chamber at the same time unit, that tends to increase bale density.

The results in Fig. 9 revealed that, increasing moisture content from 8$10 ; 11-13 ; 14-16$ and $17-19 \%$ at feed rates of $1.3 ; 2.5 ; 3.9 ; 5.2$ ton/ $\mathrm{h}$ decreased the power requirements by $11.9,8.7,6.9 \%$. The reduction in baling power by increasing material moisture content to a certain limit is mainly because the actual force required for baling materials of lower moisture content due to the elastic conditions of high moisture content. This agreement with Morad, et al. 2002. They stated that dry materials have a considerably lower modulus of elasticity and lower coefficient of friction than do materials with a higher moisture content and thus require more power to produce a given resistance force. At the same time increasing baler feed rates from $1.3 ; 2.5 ; 3.9$ and 5.2 ton/h at moisture content from $8-10 ; 11-13 ; 14-16$ and $17-19 \%$ led to increase the power requirements by $7.14,10.7,14.5 \%$ respectively. The increase in baling power by increase feed rate is attributed to the excessive material in the bale chamber, which increase the load on the baler plunger and other parts that increase the required power.

\section{SUMMARY AND CONCLUSIONS}

\section{The study conducted to the following conclusions:}

1 - The field capacity increased by $51 \%$ and field efficiency decreased by $35 \%$ when the baler forward speed increased from 1.5 to $6.0 \mathrm{~km} / \mathrm{h}$.

2- The bale productivity increased by $47 \%$ and bale density decreased by 
$33 \%$ when the baler forward speed increased from 1.5 to $6.0 \mathrm{~km} / \mathrm{h}$.

3- Increasing baler forward speed from 1.5 to $6.0 \mathrm{~km} / \mathrm{h}$ lead to increase fuel consumption rate by $53 \%$ and decrease the energy requirements by $41 \%$.

4- increasing material moisture content from 10 to $19 \%$ for barley straw increased bale density by $20 \%$ and decreased the size requirements for storing bales by $20 \%$.

5- increasing material moisture content of barley straw from 11 to $13 \%$ decreased the fuel consumption and energy required by $15 \%$.Any further moisture content increase up to19\% fuel consumption rate and energy required will increase.

6-increasing moisture content from 8-10;11-13;14-16 and 17-19\% at feed rates of $1.3 ; 2.5 ; 3.9 ; 5.2 \mathrm{ton} / \mathrm{h}$ increased the bale density by $15.2 ; 17.3 ; 18.6 \%$ respectively.

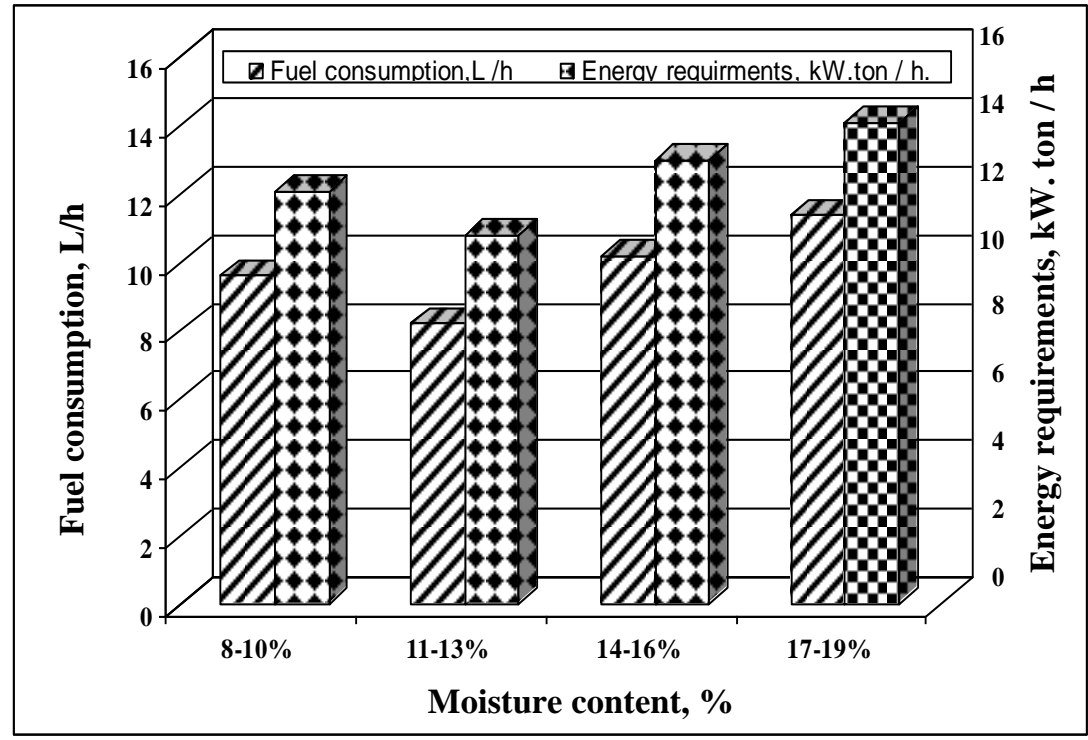

Figure (6). Effect of moisture content on the bale density and size required for storing bales. 


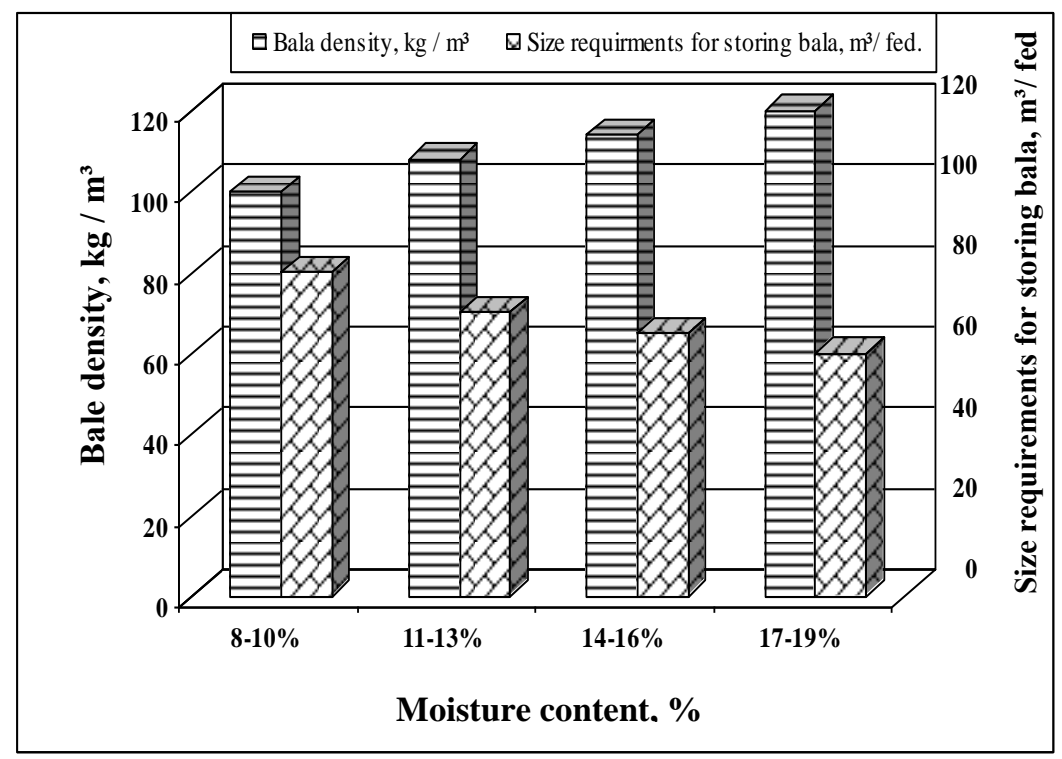

Figure (7). Effect of moisture content on the fuel consumption and energy requirements.

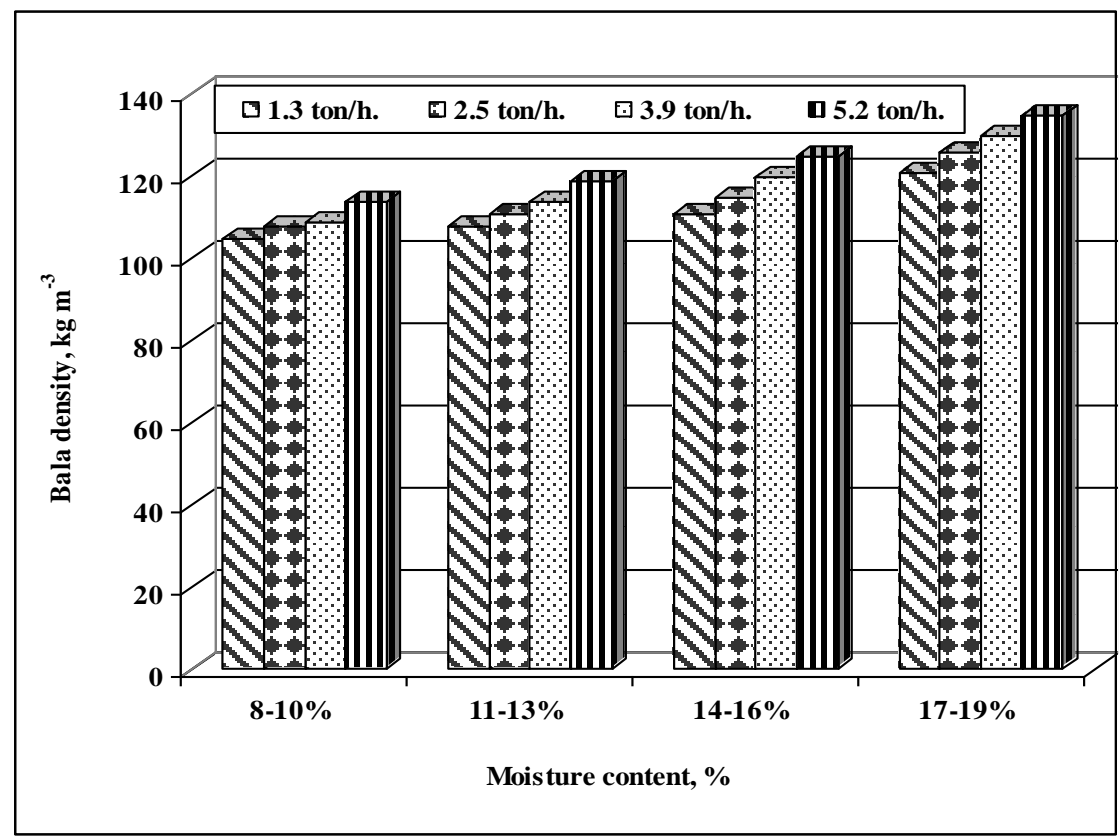

Figure (8). Effect of moisture content and baler feed rates on the bale density. 


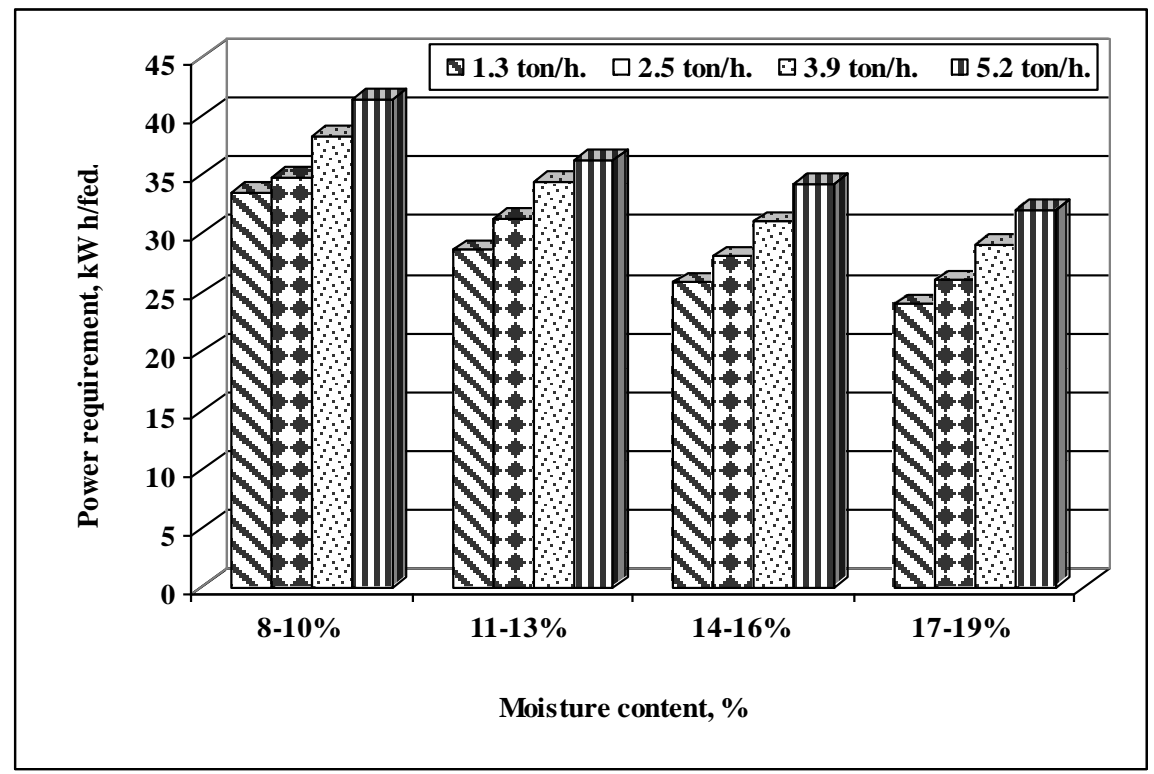

Figure (9). Effect of moisture content at different baler feed rates on the Power requirements.

7- increasing baler feed rates from $1.3 ; 2.5 ; 3.9$ and 5.2 ton/h at moisture content from $8-10 ; 11-13 ; 14-16$ and $17-19 \%$ led to increase the bale density by $11 ; 12.6 ; 14.5 \%$ respectively.

8- Forward speeds of $4-5 \mathrm{~km} / \mathrm{h}$, baler feed rate of $5.2 \mathrm{ton} / \mathrm{h}$ and moisture content of $11-13 \%$ are recommended to produce bales with an optimum power and optimum densities to increase their storage life

\section{REFERENCES}

Abd El- Mottaleb, A.F. (2002). Comparative study between pick up , stationary and round balers Miser J. Ag. Eng., 19(1) pp. 23-39. 
Afify, M. T., Bahnasawy, A. H and S. A. Ali. (2002). Effect of rice straw picking up methods on the performance of the rectangular baler. Written for presentation at the AIC 2002 Meeting CASE/ SCGR program Saskatoon, Saskatchewan july 14-17.pp. 1-15.

Afify, M. T., Bahnasawy, A. H and S. A. Ali. (2005). Effect of rice straw feeding on the performance of rectangular baler. Misr j. Ag. Eng., 22(2): 380-403.

Agricultural Magazine, (1999). The scientific face to the blak cloud towards best investment of the agricultural residues. Dec., year 41(493) pp. 17-20. (C.F. El-Gindy, et al. 2009).

ASTM, (1991). Standard D2216-90. Methods for laboratory determination of moisture content of soil. In Annual Book of ASTM Standards. 0408: 278-281. Philadelphia, PA: American Society for Testing and Materials.

El-Danasory, M. M. and A.T. Imbabi. (1998). Study of mechanical and manual pickup and baling of wheat straw after harvesting with combine. Misr j. Ag. Eng., 15(2):246-260.

El-Gindy, A. M. , Baiomy, M. A., Abd el- hamed and A. Mosa, Sahar, (2009). Design and Fabrication of A Simplified Mechanical Handling System Of Rice Straw Baling Operation To Reduce Environment Pollution. Miser J Ag. Eng., 26(1): 667-685.

Freeland, R.S. and B.L. Bledose. 1988. Energy required to form large round hay bales - Effect of operational procedure and baler chamber type. Transaction of the ASAE 31(1):63-67. 
Morad, M. M. (1996). Performance characteristics of a plunger-type field baler. Misr J. Ag. Eng. 13(2):276-286.

Morad, M. M. (2002). Performance characteristics of a plunger-type field baler. Misr. J. Eng., 13(2): 276 - 286.

Saher El. A. M. (2008). Design of Mechanical System Hooked with threshing machines to convert rice straw into bales to reduce pollution of environment, Unpublished Doctor of philosophy, Ain Shams University, Institute of Environmental Studies and Research.

Srivastava, A.K., C.E. Goering and R.P. Rothrbach. (1993). Engineering Principal of Agriculture Machines. ASAE, Textbook No.6. pp. 383-392. St. Joseph, MI: ASAE.

\section{الملخص العربيى}
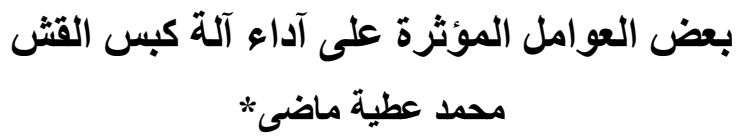

أجريت هذة الدر اسـة باحدى ألمـز ارع الخاصـة بمدينة سبها بالجماهيريـة ألعربيـة الليبيـة بهدف

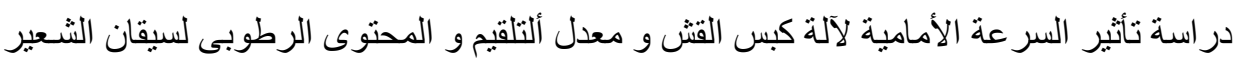

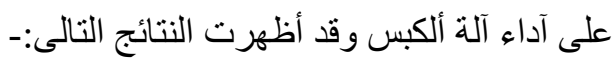

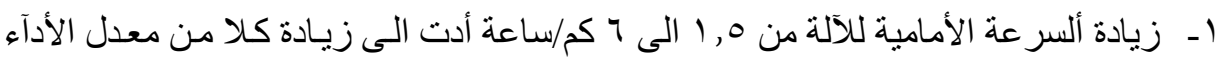

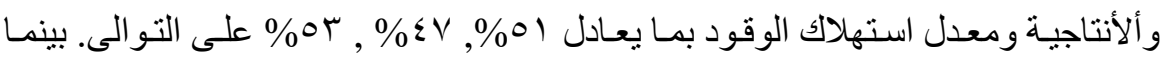

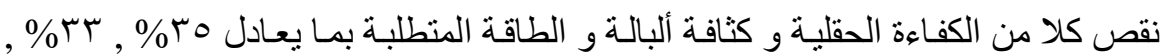

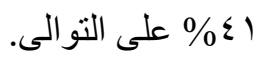

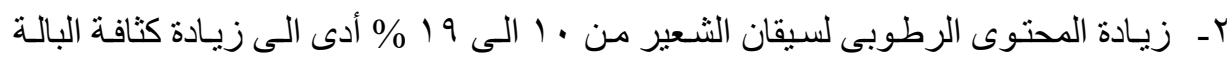

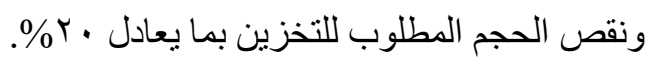

*أستاذ مساعد بقسم الهندسة الزراعية ـ كلية الزراعة - جامعة قناة السويس 


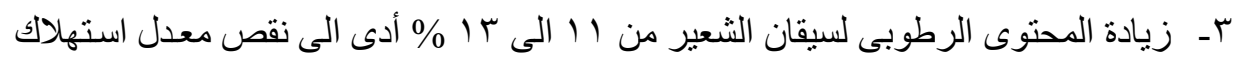

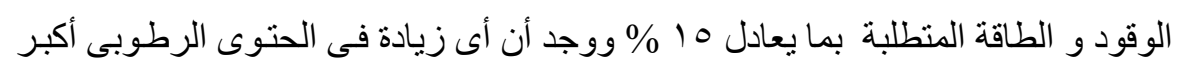
من سا \% \% وحتى 19 \% أدى الى زيادة فى معدل استهلاك الوقود و الطاقة المتطلبة.

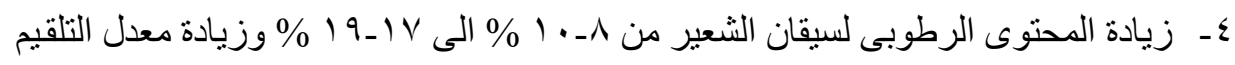

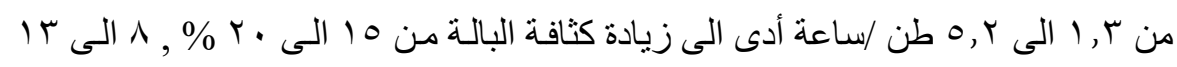

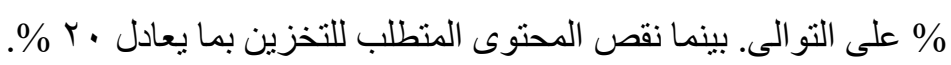

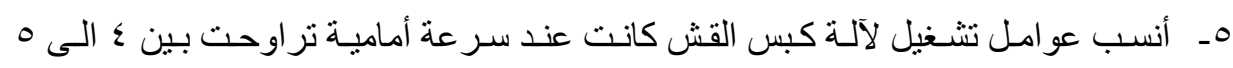

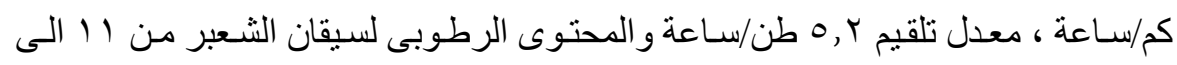
\% 